\title{
PENGARUH INFLASI TERHADAP KINERJA PEMBIAYAAN BANK SYARIAH, VOLUME PASAR UANG ANTAR BANK SYARIAH, DAN POSISI OUTSTANDING SERTIFIKAT WADIAH BANK INDONESIA
}

\author{
Saekhu
}

\begin{abstract}
Abstrak
Berdasarkan pengujian yang menggunakan metode Vector Autoregression (VAR) ternyata variabel INF mempunyai pengaruh positif terhadap variabel FDR, NPF, VPUAS dan OSWBI. Berikut dijelaskan beberapa intisari dari basil pengujian penelitian ini. Inflasi berpengaruh positif terbadap Financing to Depocit Ratio (FDR), volume transaksi Pasar Uang Berdasarkan Prinsip Syariah (VPUAS) dan posisioutstanding Sertifikat Wadiah Bank Indonesia (OSWBI). Meskipun demikian pengarubnya sangat kecil, tidak signifikan dan hanya berlangsung dalam jangka pendek saja. Babkan variabel-variabel tersebut lebih dipengarubi oleh kinerjanya di masa lalu.Tidak signifikannya pengaruh variabel INF terhadap variabel FDR, dan VPUAS disebabkan masib kecilnya kedudukan perbankan syariab sebagai faktor yang dapat mempengarubi peredaran uang di Indonesia.
\end{abstract}

Keywords: Inflasi, Pembiayaan Bank Syariah, Pasar Uang, Wadiah

\section{Pendahuluan}

Salah satu faktor yang 'mengganggu' pertumbuhan ekonomi Indonesia selama ini adalah faktor inflasi. Dalam jangka pendek inflasi bisa menguntungkan bagi produsen karena akan menaikkan tingkat harga sehingga produsen akan meningkatkan produksinya. Tetapi, masalahnya inflasi di Indonesia sangatlah kompleks, tinggi dan tidak stabil. Soegiharso dan Gitaharie, menunjukkan bahwa inflasi pada tingkat tertentu (di bawah nilai treshold), diperlukan untuk mendorong pertumbuhan ekonomi. Dalam 
Pengaruh Inflasi Terhadap Kinerja Pembiayaan Bank Syariah

kebijakan moneter di Indonesia, kenaikan tingkat inflasi akan direspon oleh otoritas moneter dengan mengeluarkan kebijakan moneter yang bersifat kontraktif seperti menaikkan tingkat suku bunga SBI. Sehingga perbankan konvensional dapat menanamkan dananya ke dalam SBI dengan tingkat bunga yang tinggi tanpa risiko yang tinggi.

Meskipun inflasi dapat menurunkan pemberian kredit ke sektor riil, kalangan perbankan (konvensional) tetap dapat meraih pendapatan yang tinggi dari bunga SBI. Keadaan ini berbeda dengan keadaan perbankan syariah. Bank syariah adalah lembaga keuangan yang tidak mengenal bunga sebagai pendapatannya. Sehingga perbankan syariah tidak dapat menempatkan likuiditasnya ke dalam SBI. Bahkan tingkat bonus Sertifikat wadiah Bank Indonesia (SWBI) jauh lebih rendah dari pada tingkat bunga SBI.

Pengaruh kebijakan moneter 'konvensional' terhadap perbankan syariah ditemukan bahwa padakontraksi moneter berupa kenaikan suku bunga SBI akan mengakibatkan pengurangandeposito, penurunan pembiayaan, serta pengurangan likuiditas perbankan syariah. Dalam menghadapi tingkat inflasi, perbankan syariah menghadapi dua masalahutama yaitu, pertama, dari sisi penghimpunan Dana Pihak Ketiga (DPK). Kenaikan tingkat inflasi akan meningkatkan suku bunga deposito. Sehingga suku bunga deposito di perbankankonvensional lebih tinggi dan menarik daripada return dari perbankan syariah. Return yang lebih tinggi di perbankan konvensional akan meningkatkan displacement atau pengalihan dana yang besar dari perbankan syariah ke perbankan konvensional. Biasanya yang melakukan displacement ini adalah nasabah korporasi. Penurunan (pertumbuhan) DPK ini akan mengurangi kemampuan bank syariah dalam mengelola likuiditasnya untuk meningkatkan pendapatan karena penurunan DPK akan menyebabkan penurunan lending capacity (Total liabilities dikurangi Giro Wajib Minimum, Cash in vault dan modal). ${ }^{1}$ Permasalahan yang kedua muncul dari sisi pembiayaan. Bagi dunia usaha, sebagai produsen barang dan jasa, inflasi dapat tmenguntungkan bila pendapatan yang diperoleh lebih tinggi dari pada kenaikan biaya produksi. Bila hal ini terjadi, produsen akan terdorong untuk melipatgandakan produksinya. Namun, bila inflasi menyebabkan naiknya biaya

1 Juda Agung, dkk, Credit Crunch di Indonesia Setelah Krisis: Fakta, Penyebab, dan Implikasi Kebijakan, Jakarta: Direktorat Riset Ekonomi dan Kebijakan Moneter Bank Indonesia, 2001, hlm. 19. 
produksi hingga pada akhirnya merugikan produsen, maka produsen enggan untuk meneruskan produksinya. Produsen bisa menghentikan produksinya untuk sementara waktu, bahkan bila tidak sanggup mengikuti laju inflasi, produsen bisa mengalami kerugian usaha. Sehingga akan berdampak pada kinerja keuangannya yang menurun.

Dampak inflasi lebih lanjut akan menyebabkan tingginya risiko default. Risiko ini akan meningkatkan Non Performing Financing (NPF) perbankan syariah. Jika pembiayaannya berdasarkan akad bagi hasil dimana jika pihak debitor mengalami kerugian usaha maka kerugian ini juga ditanggung oleh bank syariah (risk sharing). Jika jenis pembiayaannya adalah akad jual beli (murabahah) maka tingginya inflasi dapat membuat produk pembiayaan syariah secara umum menjadi relatif lebih mahal.

Tingginya risiko pembiayaan (dan atau lemahnya absorpsi sektor riil) akan menyebabkan perbankan syariah bisa mengurangi penyaluran dana ke sektor riil. Sehingga perbankan syariah akan menempatkan kelebihan likuiditasnya ke dalam SWBI atau Sertifikat Investasi Mudharabah Antarbank (IMA) di Pasar Uang Antar Bank Syariah (PUAS). Pemindahan portofolio ke dalam PUAS dan SWBI merupakan cerminan darisifat bisnis perbankan syariah di Indonesia yang masih risk averse.

Oleh karena itu berdasar perspektif di atas, akan mencoba menganalisis seberapa besar pengaruh gejolak inflasi terhadap kinerja likuiditas perbankan syariah dalam hal pembiayaan (FDR dan NPF) dan penempatan dana di dalam PUAS dan SWBI. Sedangkan tujuan penelitian ini adalah untuk mengetahui pengaruh inflasi terhadap tingkat Financing to Depocit Ratio (FDR) perbankan Syariah, tingkat Non Performing Financing (NPF) perbankan syariah, volume transaksi Pasar Uang Antar BankSyariah (PUAS), dan posisi outstanding Sertifikat Wadiah Bank Indonesia (SWBI).

\section{Inflasi}

Inflasi adalah kecenderungan dari harga-harga untuk meningkat secara umum dan terus menerus. Kenaikan beberapa komoditi saja tidak disebut inflasi, kecuali bila kenaikan tersebut meluas kepada atau mengakibatkan 
Pengaruh Inflasi Terhadap Kinerja Pembiayaan Bank Syariah

kenaikan sebagian besar dari harga barang-barang lain. Keadaan harga yang terusmenerus berarti bahwa kenaikan harga-harga karena bersifat musiman atau sesekali saja atau tidak mempunyai pengaruh lanjut tidak disebut inflasi.

Indikator inflasi adalah ukuran yang digunakan untuk menghitung nilaiinflasi untuk mengetahui tingkat inflasi pada waktu tertentu.Indikator inflasiumumnya dihitung dengan menggunakan angka indeks sekelompok harga barang danjasa.Secara umum ada tiga indikator inflasi yaitu IHK, IHPB dan PDB deflator.Pada skripsi ini indikator yang digunakan adala IHK.IHK pada umumnya digunakan untuk mengukur perubahan harga (pricechanges), biaya hidup (cost of living), daya beli (purchasing power) dan tingkat inflasi (general measure of inflation). Penjelasan penggunaan inflasi IHK dijabarkan sebagai berikut:

- Sebagai alat ukur perubahan harga (Price Changes), IHK digunakan untuk mengukur perubahan harga dari sekelompok atau sekeranjang barang dan jasa yang dikonsumsi oleh rumah tangga.

- Sebagai alat ukur biaya hidup (Cost of Living), IHK digunakan untuk mengukur perubahan biaya yang dikeluarkan untuk mendapatkan sekelompok barang dan jasa yang memberikan tingkat kepuasan yang sama, sejalan dengan perubahan preferensi rumah tangga.

- Sebagai alat ukur daya beli (Purchasing Power), IHK adalah indikator untuk mengukur seberapa banyak barang dan jasa yang dapat dibeli dari sejumlah uang tertentu.

- Sebagai alat ukur inflasi (general measure of inflation), IHK mengukur perubahan harga dalam suatu perekonomian.

Di Indonesia, IHK digunakan sebagai indikator untuk mengukur perkembanganhargasecara umum.

\section{Sertifikat Wadiah Bank Indonesia (SWBI)}

Undang-undang No.23 tahun 1999 mengamanatkan bahwa dalam melaksanakan kebijakan moneter, Bank Indonesia harus mengakomodasi perkembangan bank-bank Syariah. Seiring dengan kian berkembangnya bankbank Syariah di Indonesia, Bank Indonesia menerapkan instrumen moneter 
Syariah dengan menggunakan prinsip wadi'ah (titipan) yaitu Sertifikat Wadi'ah Bank Indonesia (SWBI) yang bertujuan untuk menarik kelebihan likuiditas bank Syariah. Dari sisi bank syariah sendiri, SWBI ini dapat dijadikan sebagai sarana penitipan dana jangka pendek.

SWBI bukanlah SBI dengan prinsip syariah, karena SWBI bukan surat berharga dan hanya sekedar bukti penitipan dana jangka pendek dengan prinsip wadi'ah. Bank Indonesia hanya memberikan bonus (return) kepada bank pemegang SWBI sepanjang penitipan tersebut diperlukan dalam rangka kontraksi moneter berdasarkan prinsip syariah. Dengan demikian SWBI tidak dimaksudkan untuk memberikan sinyal tingkat "return syariah" sebagai pengganti tingkat suku bunga pada SBI.

\section{Pasar Uang Antarbank berdasarkan prinsip Syariah (PUAS)}

Pasar Uang Antar Bank (PUAB) merupakan kegiatan pinjam meminjam dana antara satu bank dengan bank lainnya. Dimana bank yang mempunyai kelebihan dana (surplus unit) akan meminjamkan dana kepada bank yang kekurangan dana (deficit unit) dengan memberikan kompensasi/imbalan tertentu. Transaksi dalam PUAB biasa dilakukan oleh perbankan dalam kegiatan sehari-hari untuk menutupi kekurangan pendanaan (mismatch) jangka pendek.

Selain itu, pemain-pemain dalam PUAB sendiri adalah bank-bank konvensional yang mendapatkan pendapatannya berupa bunga. Sehingga pendapatan untuk transaksi dalam PUAB juga berupa bunga. Kondisi ini membuat bank syariah tidak bisa masuk ke dalam PUAB. Padahal sebagaimana layaknya lembaga bank lainnya, banksyariah membutuhkan adanya sarana PUAB antar bank syariah sendiri untuk mengelola likuiditasnya secara efisien dan optimal.

Untuk memberikan perlakuan yang setara kepada bank syariah, Bank Indonesia mulai mengeluarkan instrumen PUAB yang sesuai syariah yang dimulai ketika bank syariah di Indonesia hanya Bank Muamalat, dengan mengeluarkan Surat Berharga Pasar Uang (SBPU) mudharabah. 
Pengarub Inflasi Terbadap Kinerja Pembiayaan Bank Syariab

\section{Instrumen Investasi Mudharabah Antarbank (IMA)}

Instrumen yang digunakan dalam PUAS saat ini adalah Sertifikat Investasi Mudharabah Antar-bank (IMA). Hal ini berarti akad yang digunakan adalah mudharabah (bagi hasil) di mana keuntungan akan dibagikan kepada kedua belah pihak (pembeli dan penjual sertifikat IMA) berdasarkan nisbah yang telah disepakati sebelumnya. Tingkat Indikasi Imbalan PUAS adalah ratarata tertimbang tingkat indikasi imbalan sertifikat investasi mudharabah antarbank yang terjadi di PUAS, yang tercatat pada Pusat Informasi Pasar Uang (PIPU).

Bank penjual menggunakan metode profit sharing (pembagian keuntungan) dan jika mengalami kerugian maka bank pembeli tidak akan memperoleh imbalan. Sepanjang kerugian itu bukan disebabkan oleh kecurangan atau kelalaian bank penerbit, maka bank penanam dana akan menanggung kerugian itu maksimum sebesar nilai nominal investasi. Sertifikat IMA diterbitkan oleh kantor pusat Bank Syariah bagi bank yang seluruh kegiatannya berdasarkan prinsip syariah dan UUS. Meski demikian, bank konvensional juga dapat berpartisipasi dalam PUAS. Tetapi bank konvensional hanya dapat berperan sebagai pembeli sertifikat IMA. Sedangkan bank umum Syariah maupun UUS dapat bertindak sebagai penerbit maupun sebagai pembeli sertifikat IMA masing-masing melalui kantor pusat dan UUS-nya.

\section{Kerangka Pemikiran}

Secara umum, inflasi tentu akan berpengaruh terhadap transaksi di lembaga keuangan. Inflasi yang tercermin dari perubahan indeks harga secara umum di suatu negara akan mempengaruhi biaya dan pendapatan secara riil. Nilai pendapatan secara riil akan berkurang akan inflasi. Meskipun berpengaruh terhadap sektor jasa keuangan, seperti yang dikutip English, tingkat inflasi yang lebih tinggi akan meningkatkankapasitas sektor jasa keuangan karena masyarakat akan mengurangi transaksi riil.Pengaruh inflasi terhadap industri jasa keuangan teraplikasi lewat channel BI rate.BI rate digunakan Bank Indonesia dalam pelaksanaan kebijakan moneternya. BI rate sebagai indikator tingkat suku bunga pasar besarannya dipengaruhi oleh 
tingkat inflasi. ${ }^{2} \mathrm{BI}$ rate kemudian akan mempengaruhi suku bunga pasar uang antarbank hingga deposito. Bagaimana dengan pengaruhnya terhadap lembaga keuangan syariah, khususnya bank syariah. Bank syariah tidak mengenal bunga sebagaireturnnya. Inflasi akan berpengaruh terhadap kinerja lembaga keuangan syariah. Seperti yang diungkapkan oleh teori bejana berhubungan. ${ }^{3}$ Kebijakan moneter 'konvensional' akan mempunyai pengaruh terhadap perbankan syariah seperti misalnya tingkat sukubunga SBI. Salah satu sebabnya adalah aset perbankan syariah yang tergolong kecil. Aset industri perbankan syariah masih sebesar Rp. 22,8 triliun atau hanya 1,49 persen dari industri perbankan nasional. Sehingga fluktuasi di tingkat makro "konvensional" akan berdampak langsung terhadap kinerja perbankan syariah.

Temuan ini juga diungkapkan oleh Pramuraharjo yang dalam tesisnya ditemukan bahwa pada kontraksi moneter berupa kenaikan suku bunga SBI akan mengakibatkan pengurangan deposito, penurunan pembiayaan, serta pengurangan likuiditas perbankan syariah. Putri menambahkan bahwa tingkat suku bunga SBI juga berpengaruh positif terhadap posisi SWBI. Kenaikan inflasi lebih berpengaruh kepada penurunan DPK perbankan syariah. Mayoritas pangsa konsumen perbankan syariah adalah golongan pasar mengambang (floating market). Golongan ini adalah golongan konsumen yang lebih bersifat returnoriented. Kenaikan tingkat inflasi tentu akan meningkatkan suku bunga deposito. Sehingga suku bunga deposito di perbankan konvensional lebih tinggi dan menarik daripada return dari perbankan syariah. Return yang lebih tinggi di perbankan konvensional akan meningkatkan displacement atau pengalihan dana yang besar dari perbankan syariah ke perbankan konvensional. Biasanya yang melakukan displacement ini adalah nasabah korporasi. Penurunan pertumbuhan DPK ini akan mengurangi kemampuan bank syariah dalam mengelola likuiditasnya untuk meningkatkan pendapatan karena penurunan DPK akan menyebabkan penurunan lending capacity. Penurunan DPK tentu akan mempengaruhi pengelolaan likuiditas

\footnotetext{
2 William B. English, "Inflation and Financial Sector Size", Journal of Monetary Economics, Vol. 44 Tahun 1999, hlm. 379-400

3 Adiwarman Karim, "Bejana Berbubungan Bank Syariab”, Republika, Senin, 31 Mei 2004, hlm. 76.
}

Volume VT/Edisi 1/Mei 2015 
Pengaruh Inflasi Terhadap Kinerja Pembiayaan Bank Syariah

bank syariah. Pada studi ini pengelolaan dana perbankan syariah dibatasi pada pembiayaan ke sektor riil, transaksi di PUAS dan penitipan dana dalam SWBI.

\section{Hipotesis Penelitian}

Hipotesis dalam penelitian ini berangkat dari pengaruh negatif inflasi terhadap pembiayaan perbankan syariah. Sehingga pengelolaan likuiditas bank syariah lebih diarahkan pada instrumen yang lebih rendah risiko. Bank Syariah menghadapi dilema pengelolaaan likuiditas. Jika menyalurkan ke sekotor riil, maka risiko defaultnya tinggi.Tetapi jika ditanamkan ke dalam SWBI atau IMA maka return yang didapat rendah dan memarjinalkan fungsi intermediasi bank syariah. Diasumsikan bahwa bank syariah lebih memilih kemungkinan yang kedua karena bank syariah masih dalam tahap early growth. Sehingga bank syariah lebih memilih untuk mengelola portofolio dengan risiko yang rendah agar tidak menganggu sustainibilitas permodalan internalnya. Berikut disajikan beberpa hipotesis yang diuraikan berdasarkan variabel penelitian.

1. Hipotesis pengaruh inflasi terhadap tingkat Financing to Depocit Ratio (FDR) perbankan syariah

Terdapat pengaruh negatif antara inflasi dengan tingkat Financing to Depocit Ratio (FDR) perbankan syariah

2. Hipotesis pengaruh inflasi terhadap volume transaksi Pasar Uang Antar Bank Syariah(PUAS)

Terdapat pengaruh positif antara inflasi dengan volume transaksi Pasar UangAntar Bank Syariah (PUAS)

3. Hipotesis pengaruh inflasi terhadap posisi outstanding Sertifikat Wadiah Bank Indonesia(SWBI)

Terdapat pengaruh positif antara inflasi dengan posisi outstanding SertifikatWadiah Bank Indonesia (SWBI)

\section{Lingkup Penelitian}

Data yang digunakan dalam studi ini adalah data sekunder berupa time series bulanan yang didapat dari Statistik Perbankan Syariah (SPS), Laporan Perekonomian Indonesia (LPI), Statistik Ekonomi dan Keuangan Indonesia 
(SEKI) terbitan Bank Indonesia (SEKI-BI) dan beberapa data terbitan dari Biro Pusat Statistik (BPS). Periode pengumpulan data dilakukan mulai dari Bulan September 2006 hingga September 2014. Satuan data yang digunakan berupa milyaran Rupiah dan persentase. Satuan data dalam milyaran Rupiah digunakan oleh variable VPUAS dan OSWBI sedangkan satuan data dalam bentuk persentase digunakan variabel INF, FDR dan NPF Untuk menghilangkan permasalahan satuan data yang berbeda, satuan data dalam bentuk milyaran Rupiah terlebih dahulu dirubah dalam bentuk logaritma.

\section{Variabel penelitian}

Variabel yang digunakan dalam penelitian ini adalah:

1. Tingkat Inflasi IHK (INF)

Tingkat inflasi IHK merupakan penghitungan tingkat inflasi di Indonesia atas dasar indikator pergerakan harga rata-rata dari barang-barang pada tingkat konsumen akhir yang terjadi diperdagangkan di suatu daerah yang dihitung secara bulanan.

2. Financing To Deposit Ratio (FDR)

FDR merupakan rasio (persentase) antara Dana Pihak Ketiga (DPK) yang diterima oleh bank syariah dibandingkan dengan jumlah pembiayaan yang disalurkan.

3. Non Performing Financing (NPF)

NPF merupakan besarnya persentase pembiayaan macet yang berasal dari debitor yang tidak mampu melunasi kewajibannya sesuai dengan kesepakatan awal.

4. Volume transaksi PUAS (VPUAS)

Volume transaksi PUAS merupakan jumlah transaksi yang dilakukan dalam PUAS dengan menggunakan instrumen IMA.Satuan data PUAS adalah milyaran Rupiah.

5. Posisi outstanding SWBI (OSWBI) 
Pengaruh Inflasi Terhadap Kinerja Pembiayaan Bank Syariah

Outstanding SWBI adalah jumlah dana perbankan syariah yang ditempatkan di Bank Indonesia.

\section{Model penelitian}

Model yang digunakan dalam penelitian adalah berbentuk model bivariat : $\{$ INF, FDR $\},\{$ INF, NPF $\},\{I N F, V P U A S\},\{I N F, O S W B I\}$. Penjabaran dari model-model bivariat tersebut disajikan sebagai :

1. Pengaruh inflasi (INF) terhadap tingkat Financing to Depocit Ratio (FDR) perbankan Syariah

2. Pengaruh inflasi (INF) terhadap tingkat Non Performing Financing (NPF) perbankan syariah

3. Pengaruh inflasi (INF) terhadap volume transaksi Pasar Uang Antar Bank Syariah (VPUAS)

4. Pengaruh (INF) inflasi terhadap posisi outstanding Sertifikat Wadiah Bank Indonesia (OSWBI)

\section{Definisi dan ruang lingkup VAR}

Model-model ekonometri biasanya berbentuk model struktural. Model-model ini dibentuk berdasarkan suatu teori ekonomi. Tetapi, kadang kala teori ekonomi tidak dapat menjelaskan suatu fenomena atau mendeskripsikan hubungan antar variabel yang ingin diuji sesuai dengan landasan teorinya secara tepat. Dengan demikian penggunaan teori ekonomi saja ternyata tidak cukup dalam menyediakan spesifikasi yang tepat terhadap hubungan dinamis antar variabel atas terjadinya suatu fenomena.

Bahkan ada beberapa teori ekonomi yang saling berbeda dalam menjelaskan suatu fenomena. Sehingga seringkali pemodel bersandar pada data dalam menentukan struktur dinamik modelnya. Selain itu proses estimasi dan inferensi bisa menjadi lebih rumit karena terdapatnya variabel endogen di kedua sisi persamaan (endogenitas variabel di sisi dependen dan independen). Oleh karena itu, dibutuhkan metode lain yang tidak banyak tergantung pada teori dalam penyusunan model sebagai jalan keluar akan dilema ini. 
VAR merupakan teknik yang dapat menjawab tantangan tersebut. VAR merupakan metode lebih lanjut sebuah sistem persamaan simultan yang bercirikan pada pemanfaatan beberapa variabel ke dalam model secara bersama-sama. Jika dalam persamaan simultan terdapat variabel endogen dan eksogen, maka dalam VAR setiap variabel dianggap simetris, karena sulit untuk menentukan secara pasti apakah suatu variabel bersifat endogen atau eksogen.

Selain itu VAR (Vector Autoregression) secara luas juga digunakan untuk sistem forecasting yang berkaitan dengan kurun waktu dan untuk menganalisis dampak dinamis dari gangguan acak (random disturbance) terhadap sistem variabel.

Analisis dalam penelitian ini menggunakan Vector Autoregresion karena beberapa hal di bawah ini :

1. Model VAR dapat menjelaskan hubungan jangka panjang simultan antar variable penelitian dengan lebih baik dari pada regresi linier.

2. Penelitian ini memasukkan variabel makro ekonomi sebagai variabel yang akan diteliti pergerakannya, yaitu inflasi. Padahal menurut Rao, sebagian dari data makroekonomi mempunyai sifat non stasioner dan causality dan metode VAR lebih dapat menangkap hubungan jangka panjang pada variable makro ini lebih baik daripada metode regresi linier.

Penggunaan model VAR dalam studi ini mengacu pada beberapa referensi terutama dari kajian-kajian ekonomi moneter yang membahas pengaruh variabel makroekonomi dan kebijakan moneter terhadap kinerja variabel-variabel keuangan di sektor mikro serta transmisi moneter. Beberapa riset terdahulu yang menggunakan model VAR antara lain Holtemoller yang menggunakan IRF VAR suku bunga kredit dan kredit terhadap perubahan variabel moneter. Arsana menggunakan VAR untuk melihat pengaruh nilai tukar terhadap aliran kredit dan mekanisme transmisi kebijakan moneter jalur kredit. ${ }^{4}$ Selain itu juga terdapat Fung yang menggunakan model VAR untuk

\footnotetext{
${ }^{4}$ I Gede Putra Arsana, "Pengaruh Nilai Tukar Terhadap Aliran Kredit dan Mekanisme Transmisi Kebijakan Moneter Jalur Kredit", Jurnal Ekonomi dan Pembangunan Indonesia,Vol. V No. 02, Januari 2005, hlm. 121-140
} 
Pengarub Inflasi Terhadap Kinerja Pembiayaan Bank Syariah

mempelajari efek shock kebijakan moneter pada perekonomian di tujuh negara di Asia timur. ${ }^{5}$

\section{Uji Stasioneritas Data}

Berdasarkan grafik 4.1, periode yang digunakan dalam penelitian ini memiliki beberapa structural break, karena itu uji unit rootnya tidak menggunakan Augmented Dickey Fuller test, melainkan dengan Phillip Pheron (PP). Nilai statistik PP dibandingkan dengan nilai kritis (critical value) MacKinnon untuk mengetahui derajat integrasi stasioneritas suatu variabel. Suatu variabel disebut stasioner pada integrasi tertentu jika nilai PP lebih kecil dari nilai kritis MacKinnon.

Dengan membandingkan nilai PP dengan nilai kritis, dapat dilihat keberadaan unit root dari setiap variabel yang digunakan dalam model. Setelah diadakan uji unit root, maka diketahui bahwa INF, FDR, OWSBI, dan VPUAS tidak stasioner pada tingkat level. Setelah dilakukan uji unit root pada 1 st difference barulah semua series menjadi stasioner, baik pada alpha 1\%, 5\% maupun $10 \%$.Karena itu, series ini dapat dilanjutkan pada tahapan berikutnya dengan menggunakan VAR in difference.

Di bawah ini adalah hasil uji unit root menggunakan metode PP pada 1 st difference dari semua variabel:

Tabel 4.1.

Hasil Estimasi Uji Akar Unit Pada Tingkat Diferensi

\begin{tabular}{|l|c|c|c|}
\hline \multirow{2}{*}{ Variabel } & \multicolumn{3}{|c|}{ PP Test Statistic } \\
\cline { 2 - 4 } & Intercept & $\begin{array}{c}\text { Trend and } \\
\text { Intercept }\end{array}$ & None \\
\hline INFLASI & $-8.005^{* * *}$ & $-7.9615^{* * *}$ & $-8.0396^{* * *}$ \\
\hline FDR & $-4,3012^{* * *}$ & $-6,0344^{* * *}$ & $-2,0174^{* * *}$ \\
\hline SBI & $-3,970^{* * *}$ & $-3,9625^{* *}$ & $-3,9255^{* * *}$ \\
\hline PUAS & $-16,747 * * *$ & $-16,758^{* * *}$ & $-16,447 * * *$ \\
\hline
\end{tabular}

Sumber: Data sekunder yang diolah, 2015.

\footnotetext{
${ }^{5}$ Ben S C. Fung, "a VAR model is used to study the effects of monetary policy shocks in seven East Asian economies", BIS Working Papers No. 119, 2002, hlm. 68
} 


\section{Penentuan selang optimal (optimal lag)}

Lag optimal adalah lag yang maksimum yang dapat diterima oleh sistem VAR yang stabil karena proses ini dilakukan untuk mencari lag maksimum yang dapat memberikan informasi yang cukup untuk melakukan uji-uji selanjutnya sekaligus menghindari parameter yang berlebihan (overparameterization).

Tabel 4.2.

Lag Maksimum VAR pada Semua Model Bivariat

\begin{tabular}{ccccccc}
\hline \hline Lag & LogL & LR & FPE & AIC & SC & HQ \\
\hline \hline 0 & -94.88154 & NA & 0.000108 & 2.222057 & 2.333906 & 2.267140 \\
1 & 447.0433 & 1022.959 & $7.99 \mathrm{e}-10$ & -9.596479 & -9.037235 & -9.371064 \\
2 & 483.4539 & 65.45715 & $5.06 \mathrm{e}-10$ & -10.05514 & $-9.048504^{*}$ & $-9.649396^{*}$ \\
3 & 506.4381 & 39.25402 & $4.35 \mathrm{e}-10 *$ & $-10.21209 *$ & -8.758058 & -9.626013 \\
4 & 514.6565 & 13.29720 & $5.24 \mathrm{e}-10$ & -10.03723 & -8.135796 & -9.270814 \\
5 & 536.5515 & $33.45752^{*}$ & $4.67 \mathrm{e}-10$ & -10.16970 & -7.820872 & -9.222953 \\
6 & 552.0942 & 22.35354 & $4.84 \mathrm{e}-10$ & -10.15942 & -7.363200 & -9.032345 \\
7 & 565.9977 & 18.74620 & $5.26 \mathrm{e}-10$ & -10.11231 & -6.868691 & -8.804899 \\
8 & 577.1537 & 14.03900 & $6.17 \mathrm{e}-10$ & -10.00345 & -6.312442 & -8.515712 \\
\hline \hline
\end{tabular}

* indicates lag order selected by the criterion

LR: sequential modified LR test statistic (each test at 5\% level)

FPE: Final prediction error

AIC: Akaike information criterion

SC: Schwarz information criterion

HQ: Hannan-Quinn information criterion

Sumber: Data sekunder yang diolah, 2015.

Setelah diketahui bahwa lag maksimum pada berbagai model bivariat maka dilakukan uji seleksi lag agar dari banyaknya lag yang ditawarkan, lag yang paling optimum dapat segera ditentukan. Penentuan lag optimal yang 
Pengaruh Inflasi Terhadap Kinerja Pembiayaan Bank Syariah

digunakan dalam penelitian ini berdasarkan lag terpendek dengan menggunakan Hannan Quinnon (HQ). Hasilnya menunjukkan bahwa model persamaan mengalami lag optimal pada lag 2 (Tabel 4.2).

\section{Pengujian hubungan kointegrasi}

Alternatif uji kointegrasi yang sekarang banyak digunakan adalah uji kointegrasi yang dikembangkan Johansen.Uji yang dikembangkan Johansen dapat digunakan untuk menentukan kointegrasi sejumlah variabel.hasil uji kointegrasi Johansen dapat dilihat pada Tabel 4.3.

Tabel 4.3.

Hasil Uji Kointegrasi Johansen

\begin{tabular}{|c|c|c|c|c|}
\hline \multicolumn{5}{|c|}{ Unrestricted Cointegration Rank Test (Trace) } \\
\hline $\begin{array}{l}\text { Hypothesized } \\
\text { No. of CE(s) }\end{array}$ & Eigenvalue & $\begin{array}{l}\text { Trace } \\
\text { Statistic }\end{array}$ & $\begin{array}{l}0.05 \\
\text { Critical Value }\end{array}$ & Prob.** \\
\hline None * & 0.230745 & 52.20420 & 47.85613 & 0.0185 \\
\hline At most 1 & 0.146092 & 29.54488 & 27.79707 & 0.0290 \\
\hline At most 2 & 0.094104 & 17.69927 & 15.49471 & 0.0263 \\
\hline At most 3 & 0.035617 & 3.409122 & 3.841466 & 0.0648 \\
\hline
\end{tabular}

Pada Tabel 4.3. hasil uji kointegrasi menunjukkan nilai absolut Trace Statistic lebih besar dari nilai kritis pada tingkat signifikansi 5 persen. Dari hasil uji kointegrasi Johansen, dapat disimpulkan bahwa variabel Inflasi (INF), FDR, suku bunga Sertifikat Bank Indonesia (SBI), dan tingkat bagi hasil pinjaman pasar uang antarbank syariah (PUAS) saling berkointegrasi pada tingkat signifikansi 5 persen.

\section{Bentuk urutan variabel (ordering)}

Suatu sistem VAR yang stabil dan baik akan memberikan output yang konsisten, terlepas pada bentuk ordering variabelnya. Kondisi ini baru terjadi 
apabila korelasi di antara residual variabel di dalam sistem memiliki nilai lebih kecil dari 0,2 karena nilai korelasi yang lebih besar dari 0,2 mengindikasikan kebutuhan akan ordering variabel

Tabel 4.4.

Matriks Korelasi Antar Variabel

\begin{tabular}{ccccc} 
& LOG(INF) & LOG(FDR) & LOG(SBI) & LOG(PUAS) \\
LOG(INF) & 1 & 0.05657 & 0.25058 & 0.01573 \\
LOG(FDR) & 0.05657 & 1 & -0.1196 & -0.2105 \\
LOG(SBI) & 0.2506 & -0.1196 & 1 & 0.05899 \\
LOG(PUAS) & 0.01573 & -0.2105 & 0.05899 & 1 \\
\multicolumn{5}{c}{ Sumber: Data sekunder yang diolah, 2015. }
\end{tabular}

\section{Implementasi VAR}

Implementasi VAR untuk mengetahui pengaruh inflasi terhadap FDR, NPF, Volume transaksi PUAS dan posisi outstanding SWBI menggunakan variance decomposition dan impulse response.Berikut dibawah ini adalah penjelasan dari uji hipotesis yang dilakukan dengan dua metode, yaitu Variance Decomposition (VED) dan Impulse Response Function (IRF).

\section{Estimasi Model VAR}

Persamaan di bawah ini menunjukkan hasil estimasi model VAR. Dalam penelitian ini, digunakan empat model VAR sesuai dengan jenis suku bunga perbankan yang digunakan.

Tabel. 4.5.

Hasil Estimasi Model VAR

\begin{tabular}{ccccc}
\hline \hline & & \multicolumn{3}{c}{ LOG(OSWB LOG(VPUA } \\
& LOG(INF) & LOG(FDR) & I) & S) \\
\hline \hline LOG(INF(-1)) & 1.115973 & 0.017751 & 0.050319 & -0.307910 \\
& $(0.10833)$ & $(0.01833)$ & $(0.01992)$ & $(0.16756)$ \\
& {$[10.3017]$} & {$[0.96834]$} & {$[2.52542]$} & {$[-1.83758]$} \\
LOG(INF(-2)) & -0.294199 & 0.007396 & -0.034681 & 0.245017
\end{tabular}


Pengarub Inflasi Terbadap Kinerja Pembiayaan Bank Syariab

\begin{tabular}{|c|c|c|c|c|}
\hline & $\begin{array}{c}(0.11236) \\
{[-2.61841]}\end{array}$ & $\begin{array}{c}(0.01901) \\
{[0.38896]}\end{array}$ & $\begin{array}{r}(0.02067) \\
{[-1.67817]}\end{array}$ & $\begin{array}{r}(0.17380) \\
{[1.40980]}\end{array}$ \\
\hline $\operatorname{LOG}(\operatorname{FDR}(-1))$ & $\begin{array}{r}-0.401880 \\
(0.65170) \\
{[-0.61667]}\end{array}$ & $\begin{array}{r}0.968868 \\
(0.11028) \\
{[8.78527]}\end{array}$ & $\begin{array}{r}-0.009801 \\
(0.11987) \\
{[-0.08176]}\end{array}$ & $\begin{array}{r}0.455767 \\
(1.00804) \\
{[0.45213]}\end{array}$ \\
\hline $\operatorname{LOG}(\operatorname{FDR}(-2))$ & $\begin{array}{c}0.408180 \\
(0.64272) \\
{[0.63509]}\end{array}$ & $\begin{array}{r}0.014290 \\
(0.10876) \\
{[0.13138]}\end{array}$ & $\begin{array}{c}0.007831 \\
(0.11821) \\
{[0.06625]}\end{array}$ & $\begin{array}{r}-0.368758 \\
(0.99415) \\
{[-0.37093]}\end{array}$ \\
\hline LOG(OSWBI(-1)) & $\begin{array}{r}1.145035 \\
(0.46626) \\
{[2.45580]}\end{array}$ & $\begin{array}{r}-0.128501 \\
(0.07890) \\
{[-1.62861]}\end{array}$ & $\begin{array}{c}1.552261 \\
(0.08576) \\
{[18.1003]}\end{array}$ & $\begin{array}{r}0.484405 \\
(0.72121) \\
{[0.67166]}\end{array}$ \\
\hline LOG(OSWBI(-2)) & $\begin{array}{r}-0.926985 \\
(0.43769) \\
{[-2.11792]}\end{array}$ & $\begin{array}{r}0.036717 \\
(0.07407) \\
{[0.49572]}\end{array}$ & $\begin{array}{r}-0.605016 \\
(0.08050) \\
{[-7.51537]}\end{array}$ & $\begin{array}{r}-0.076040 \\
(0.67701) \\
{[-0.11232]}\end{array}$ \\
\hline LOG(VPUAS(-1)) & $\begin{array}{r}-0.014098 \\
(0.06965) \\
{[-0.20241]}\end{array}$ & $\begin{array}{r}0.002467 \\
(0.01179) \\
{[0.20931]}\end{array}$ & $\begin{array}{c}0.015378 \\
(0.01281) \\
{[1.20039]}\end{array}$ & $\begin{array}{r}0.485835 \\
(0.10773) \\
{[4.50958]}\end{array}$ \\
\hline LOG(VPUAS(-2)) & $\begin{array}{r}-0.079429 \\
(0.06578) \\
{[-1.20747]}\end{array}$ & $\begin{array}{r}-0.009595 \\
(0.01113) \\
{[-0.86194]}\end{array}$ & $\begin{array}{r}-0.025933 \\
(0.01210) \\
{[-2.14338]}\end{array}$ & $\begin{array}{r}0.152957 \\
(0.10175) \\
{[1.50326]}\end{array}$ \\
\hline $\mathrm{C}$ & $\begin{array}{r}-0.000659 \\
(0.43497) \\
{[-0.00152]}\end{array}$ & $\begin{array}{r}0.357439 \\
(0.07361) \\
{[4.85599]}\end{array}$ & $\begin{array}{c}0.118962 \\
(0.08000) \\
{[1.48695]}\end{array}$ & $\begin{array}{r}-0.989198 \\
(0.67281) \\
{[-1.47025]}\end{array}$ \\
\hline R-squared & 0.911939 & 0.999212 & 0.986560 & 0.580182 \\
\hline Adj. R-squared & 0.903747 & 0.999139 & 0.985309 & 0.541129 \\
\hline Sum sq. resids & 1.785846 & 0.051142 & 0.060416 & 4.272794 \\
\hline S.E. equation & 0.144103 & 0.024386 & 0.026505 & 0.222898 \\
\hline F-statistic & 111.3244 & 13635.31 & 789.0819 & 14.85633 \\
\hline Log likelihood & 53.96510 & 222.7349 & 214.8190 & 12.52727 \\
\hline Akaike AIC & -0.946634 & -4.499683 & -4.333032 & -0.074258 \\
\hline Schwarz SC & -0.704687 & -4.257737 & -4.091085 & 0.167688 \\
\hline Mean dependent & 1.972118 & 9.774980 & 2.160931 & 1.761058 \\
\hline S.D. dependent & 0.464479 & 0.831041 & 0.218679 & 0.329050 \\
\hline
\end{tabular}

Sumber: Data sekunder yang diolah, 2015. 
Tabel 4.6.

Variance Decomposition

\begin{tabular}{cccccc}
\hline \hline \multicolumn{5}{c}{$\begin{array}{c}\text { Perio } \\
\mathrm{d}\end{array}$} & \multicolumn{5}{c}{$\begin{array}{c}\text { Variance Decomposition of LOG(INF): } \\
\text { LOG(OSW }\end{array}$} & $\begin{array}{c}\text { LOG(VPU } \\
\text { AS) }\end{array}$ \\
\hline \hline 1 & 0.144103 & 100.0000 & 0.000000 & 0.000000 & 0.000000 \\
2 & 0.223501 & 97.94829 & 0.348035 & 1.684815 & 0.018862 \\
3 & 0.280393 & 94.18170 & 0.491445 & 4.875166 & 0.451689 \\
4 & 0.324566 & 89.90181 & 0.550297 & 8.328842 & 1.219052 \\
5 & 0.359939 & 85.84834 & 0.564053 & 11.36558 & 2.222019 \\
6 & 0.388398 & 82.36558 & 0.557660 & 13.74431 & 3.332458 \\
7 & 0.411045 & 79.52543 & 0.543388 & 15.46919 & 4.461994 \\
8 & 0.428720 & 77.28168 & 0.527367 & 16.64068 & 5.550270 \\
9 & 0.442178 & 75.54744 & 0.512480 & 17.38155 & 6.558527 \\
10 & 0.452129 & 74.23094 & 0.499940 & 17.80660 & 7.462522 \\
\hline \hline
\end{tabular}

Sumber: Data sekunder yang diolah, 2015.

\section{Pengaruh INF terhadap FDR}

Dari Hasil analisa variance decomposition model INF dan FDR dapat disimpulkan bahwa INF tidak secara signifikan mempengaruhi FDR. FDR lebih dipengaruhi oleh kinerjanya di masa lalu. Bahkan pengaruh inflasi terhadap FDR perbankan syariah hanya berlaku dalam jangka pendek. Hal ini dapat dilihat dengan nilai Standar Error (SE) yang cukup tinggi. Tidak signifikannya pengaruh inflasi terhadap FDR dikarenakan bank syariah tidak memakai mekanisme suku bunga. Sehingga tingkat bagi hasil atau marjin laba produk bank syariah tidak harus 'menyesuaikan' diri dengan tingkat inflasi seperti layaknya tingkat suku bunga bank konvesional. Untuk melihat respon variabel FDR terhadap perubahan INF. Di bawah ini adalah grafik IRF dari variabel INF terhadap FDR: 
Pengarub Inflasi Terhadap Kinerja Pembiayaan Bank Syariah

\section{Grafik 4.1.IRF INF terhadap FDR}

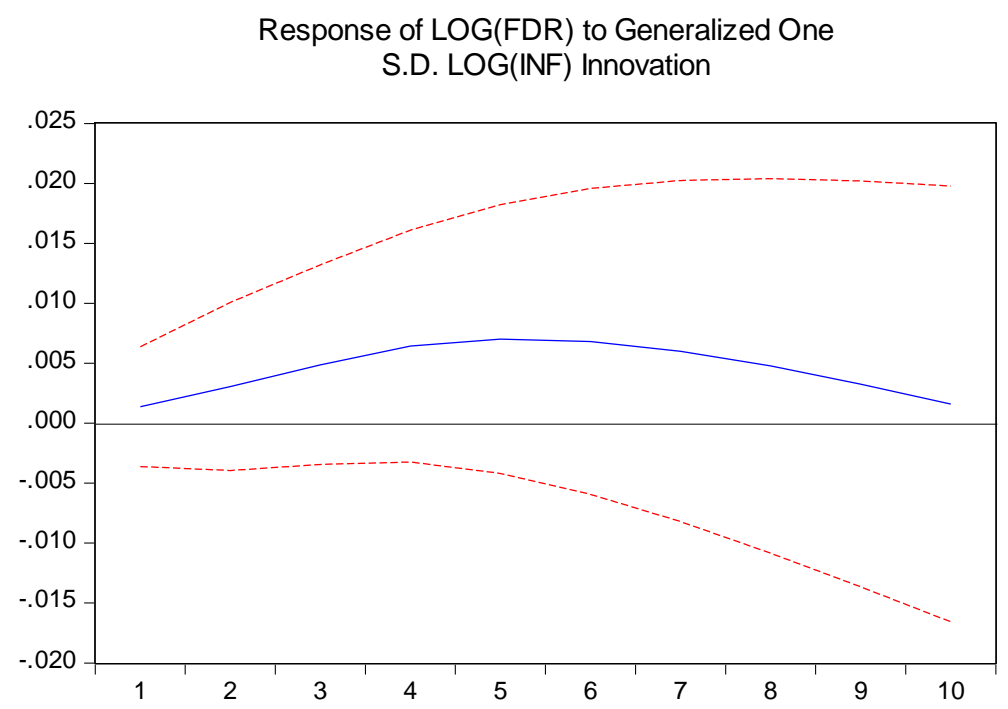

Sumber: Data sekunder yang diolah, 2015.

Grafik IRF accumulated responses dari variabel INF terhadap variabel FDR mempunyai slope positif. Hal ini berarti pergerakan inflasi searah dengan pergerakan FDR perbankan syariah. Meskipun demikian pengaruhnya tidak terlalu signifikan karena grafiknya tidak naik dengan tajam. Hasil pengujian berarti mematahkan hipotesis awal penelitian yang menyatakan bahwa inflasi berpengaruh negatif terhadap FDR perbankan syariah. Tingkat suku bunga bank konvensional mengacu pada tingkat BI rate yang merupakan indikator suku bunga pasar di mana BI rate sudah mengakomodir tingkat inflasi. Sehingga tingkat suku bunga pasar pasti lebih besar dari pada tingkat inflasi supaya nilai riilnya lebih tinggi untuk meNdapatkan marjin keuntungan riil.

Tetap naiknya FDR perbankan syariah ketika terjadi kenaikan inflasi menandakan bahwa perbankan syariah tidak terlalu 'takut' akan kehadiran inflasi dalam hal penyaluran pembiayaan. Penyaluran pembiayaan harus tetap dilakukan bank syariah karena jika tidak akan menghadapi risiko bleeding karena alternatif penempatan likuiditasnya masih terbatas. Bleeding merupakan kondisi dimana bank tidak dapat membayar return dari investasi (deposito) nasabah karena bank tidak dapat mengelola dana nasabah tersebut untuk memberikan keuntungan bagi bank sehinga bank dapat membayar return untuk nasabah. Tetapi sayangnya, jika dilihat dari komposisi pembiayaan perbankan syariah, 
masih didominasi oleh pembiayaan murabahah. Padahal pola pembiayaan berbasis bagi hasil merupakan esensi pembiayaan bank syariah. Pembiayaan berbasis bagi hasil lebih condong untuk menggiatkan sektor riil karena meningkatkan hubungan langsung dan pembagian risiko antara bank syariah dengan debitor. Bahkan pengembangan produk yang terjadi di perbankan syariah lebih berbasis pada produk layanan konsumen (consumer banking) seperti produk pembiayaan perumahan.

Masih dominannya pembiayaan berbasis murabahah memuat bank syariah masih bersifat risk avoide. Apalagi portofolio pembiayaan bank syariah juga didominasi financing kepada sektor Usaha Kecil dan Menengah (UKM) dan penggunaannya untuk kebutuhan modal kerja. Padahal menurut Rosly dalam skema mudharabah, inflasi bukan perhatian utama. Karena dalam mudharabah, keuntungan tidak ditentukan di awal kontrak, tetapi direalisasikan sejalan dengan kondisi ekonomi. Ketika terjadi inflasi, tingkat harga naik, penjualan dan keuntungan diperkirakan naik juga. Dalam sisi liabilitas, kenaikan inflasi akan meningkatkan return mudharabah. ${ }^{6}$

Penyaluran pembiayaan berbasis bagi hasil lebih menggunakan pola linkage bank syariah dengan lembaga keuangan lainnya seperti BPRS, koperasi dan pegadaian. Peningkatan kerjasama linkage ini merupakan salah satu sarana yang membuat penyaluran likuiditas bank syariah tetap tinggi. Kenaikan inflasi lebih berpengaruh kepada penurunan DPK perbankan syariah. Penurunan DPK terjadi karena tingkat suku bunga deposito perbankan konvensional menjadi tinggi. Kenaikan tingkat suku bunga deposito perbankan konvensional menyebabkan peningkatan risiko displacement atau pengalihan dana dari bank syariah ke bank konvensional. Penurunan DPK bisa mengurangi lending capacity bank syariah.

\section{Pengaruh INF terhadap VPUAS}

Dari tabel variance decomposition di atas dapat diketahui bahwa pengaruh INF terhadap VPUAS sangat kecil. Dilihat dari Standard Error-nya, pengaruhnya pun hanya terjadi dalam jangka pendek saja. Meskipun semakin

\footnotetext{
${ }^{6}$ Saiful Azhar Rosly, Mudharabah Interbank Investment, The Sun (Malaysia), Friday, Februari 16, 1996
} 
Pengarub Inflasi Terbadap Kinerja Pembiayaan Bank Syariab

lama pengaruhnya semakin meningkat. Variabel VPUAS lebih dipengaruhi oleh kinerjanya di masa lalu.

\section{Grafik 4.2.IRF INF terhadap VPUAS}

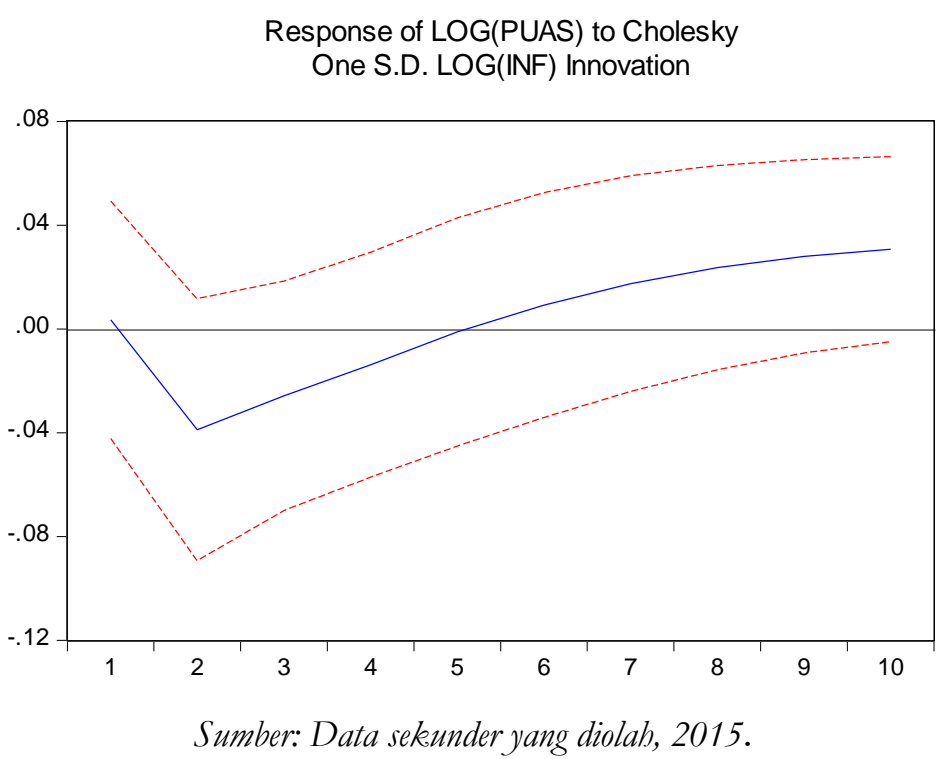

Grafik accumulated response dari variabel INF terhadap variabel VPUAS mempunyai slope positif yang dimulai pada bulan ke 2 . Hal ini menandakan bahwa pergerakan volume transaksi VPUAS bergerak searah dengan laju inflasi yang berarti kebutuhan likuiditas jangka pendek bank syariah naik pada saat terjadi inflasi. Walaupun secara nasional perbankan syariah terlihat likuid namun per masing-masing bank bukan tidak mungkin terdapat bank yang kekurangan likuiditas.

Naiknya kebutuhan likuiditas sementara terjadi karena bank permodalan bank syariah masih rentan terhadap adanya shock dalam perekonomian meskipun pengaruhnya tidak secara langsung.Karena inflasi, meskipun pengaruhnya kecil bagi bank syariah, dapat meningkatkan risiko default debitor dan menyebabkan terjadi temporary illikuid.

Kekhawatiran ini diakibatkan oleh masih rendahnya modal bank syariah. Apalagi biasanya pihak yang bermain sebagai penjual sertifikat IMA adalah Unit Usaha Syariah (UUS). Modal UUS masih ditunjang oleh bank induknya, sehingga UUS sangat hati-hati (prudent) dalam manajemen 
pembiayaannya ketika terjadi gejolak dalam perekonomian agar modal (CAR) tidak turun.

\section{Pengaruh INF terhadap OSWBI}

Dari hasil dekomposisi varians variabel INF terhadap OSWBI dalam 12 periode diketahui bahwa variabel INF mempengaruhi variabel OSWBI secara signifikan dan semakin panjang periodenya pengaruh itu semakin kuat. OSWBI sendiri secara signifikan dipengaruhi oleh pergerakan nilainya dimasa lalu.

\section{Grafik 4.3. IRF INF terhadap OSWBI}

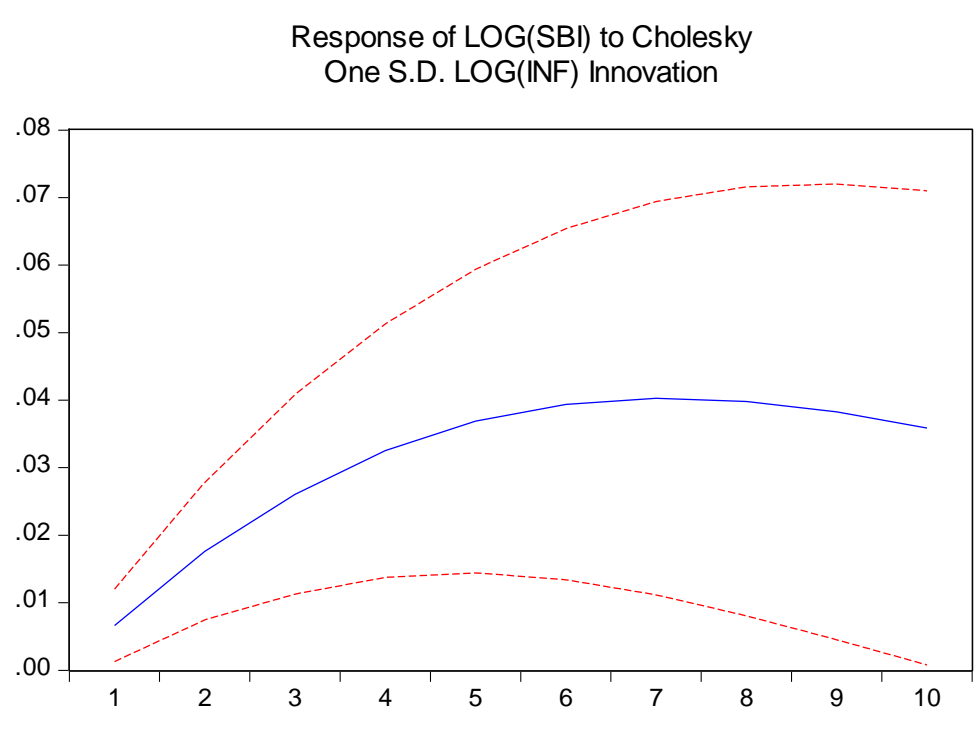

Sumber: Data sekunder yang diolah, 2015.

Grafik accumulated response dari variabel INF terhadap variabel OSWBI mempunyai slope negatif yang dimulai pada bulan ke-8 sehingga dapat diartikan bahwa setiap kenaikan posisi INF, akan direspon dengan kenaikan SWBI. Kenaikan outstanding SWBI ketika terjadi kenaikan inflasi disebabkan SWBI tidak mempunyai risiko default. Tetapi karena bonus yang diberikan dari penempatan dana di SWBI kecil maka proporsi penempatan dana di SWBI juga tidak besar. Selain disalurkan untuk melakukan ekspansi pembiayaan, DPK juga dipakai untuk tujuan investasi fisik seperti melakukan perluasan 
Pengaruh Inflasi Terhadap Kinerja Pembiayaan Bank Syariah

jaringan kantor dan layanan perbankan dan menutup biaya operasional karena peningkatan biaya pembentukan cadangan penghapusan atas risiko kerugian.

\section{Kesimpulan}

Penelitian ini bertujuan untuk menganalisis pengaruh dari inflasi IHK (INF) terhadap kinerja pembiayaaan perbankan syariah yang diukur dengan kriteria Financing to Depocit Ratio (FDR), volume transaksi Pasar Uang Berdasarkan Prinsip Syariah (VPUAS) dan posisioutstanding Sertifikat Wadiah Bank Indonesia (OSWBI). Berdasarkan pengujian yang menggunakan metode Vector Autoregression ( $V A R$ ) ternyata variabel INF mempunyai pengaruh positif terhadap variabel FDR, NPF, VPUAS dan OSWBI. Berikut dijelaskan beberapa intisari dari hasil pengujian penelitian ini.

Inflasi berpengaruh positif terhadapFinancing to Depocit Ratio (FDR), volume transaksi Pasar Uang Berdasarkan Prinsip Syariah (VPUAS) dan posisioutstanding Sertifikat Wadi'ah Bank Indonesia (OSWBI). Meskipun demikian pengaruhnya sangat kecil, tidak signifikan dan hanya berlangsung dalam jangka pendek saja. Bahkan variabel-variabel tersebut lebih dipengaruhi oleh kinerjanya di masa lalu. Tidak signifikannya pengaruh variabel INF terhadap variabel FDR, dan VPUAS disebabkan masih kecilnya kedudukan perbankan syariah sebagai faktor yang dapat mempengaruhi peredaran uang di Indonesia.

Konklusi dari hasil penelitian ini bahwa perilaku perbankan syariah berbeda dengan perbankan konvensional. Basis pendapatan bank konvensional adalah bunga.Tingkat suku bunga tidak mencerminkan biaya kredit ke sektor riil, melainkan merupakan cerminan BI rate yang merupakan suku bunga pasar yang mengakomodir tingkat inflasi.Sehingga terdapat hubungan yang negatif antara sektor riil dengan sektor moneter. Di saat sektor riil membutuhkan tambahan dana investasi untuk bisa bertahan atau melakukan ekspansi di tengah-tengah inflasi, tingkat suku bunga bank konvensional malah naik seriring kenaikan inflasi. Sedangkan bank syariah, sebagai bank yang bersentuhan langsung dengan sektor riil, 'fee' pembiayaan yang dikenakan kepada debitor merupakan cerminan dari keseimbangan antara penawaran dan permintaan pembiayaan yang sesungguhnya. 


\section{DAFTAR PUSTAKA}

Agung, Juda, Bambang Kusmiarso, Bambang Pramono, Erwin G. Hutapea, Andry Prasmuko, Nugroho Joko Prastowo, Credit Crunch di Indonesia Setelah Krisis: Fakta, Penyebab, dan Implikasi Kebijakan, Jakarta: Direktorat Riset Ekonomi dan Kebijakan Moneter Bank Indonesia, 2001

Al-Mushlih, Abdullah dan Shalah ash-Shawi, Fikib Ekonomi Keungan Islam (terjemahan), Jakarta: Darul Haq, 2004

Antonio, Muhammad Syafi'i, Bank Syariah dari Teori ke Praktik, Jakarta: Gema Insani Press, 2001

Arsana, I Gede Putra, "Pengaruh Nilai Tukar Terhadap Aliran Kredit dan Mekanisme Transmisi Kebijakan Moneter Jalur Kredit”, Jurnal Ekonomi dan Pembangunan Indonesia, Vol. V, No. 02, 2005 Januari, hal 121-140

Ascarya (editor), Mencari Solusi Pembiayaan Bagi Hasil Perbankan Syariah, Jakarta: Bank Indonesia, 2004

dan Diana Yumanita, Bank Syariah: Gambaran Umum,Jakarta: Bank Indonesia, 2005

Buchori, Ahmad, "Mengenal PUAS dan SWBI sebagai Piranti Pasar Uang dan Moneter Syariah”, Wacana, Edisi 2, Agustus 2001

Dewan Syariah Nasional, Himpunan Fatwa Dewan Syariah Nasional,Jakarta: MUI dan BI, 2003

Direktorat Perbankan Syariah, Laporan Perbankan Syariah tabun 2005, Jakarta: Bank Indonesia, 2006

Enders, Walter, Applied Econometric Time Series, New York: John Wiley and Sons, 1995

English, William B, "Inflation and Financial Sector Size", Journal of Monetary Economics, Vol. 44, Tahun 1999, hal. 379-400

Fung, Ben S C, “a VAR model is used to study the effects of monetary policy shocks in seven East Asian economies", BIS Working Papers, No. 119, 2002

Gambacorta, Leonardo, "Bank-specific Characteristics and Monetary Policy Transmission: The Case of Italy", ECB Working Paper Series, 2001 
Pengarub Inflasi Terhadap Kinerja Pembiayaan Bank Syariah

Hadad, Muliaman D dkk, "Studi Biaya Intermediasi Beberapa Bank Besar di Indonesia: Apakah Bunga Kredit Bank Umum Overpriced ?, BI Working Paper, 2003

Heatubun, S. Donny handoko dkk, Kajian tentang Instrumen Moneter Pada Perbankan Syariah, PCS-BI Angkatan I Kelompok D. Direktorat Riset Ekonomi dan Kebijakan Moneter Bank Indonesia, Januari, 2000

Karim, Adiwarman, Bank Islam: Analisis Fiqh dan Kenangan, Jakarta : IIIT, 2001 2004 , "Bejana Berhubungan Bank Syariah", Republika, Senin, 31 Mei

Karim, Yustika T, "Prospek dan Tantangan Perbankan Syariah 2006", Economic Review Journal, No. 202, Desember 2005

Lewis, K. Mervyn dan Latifa M. Algaoud, Islamic Banking, Northampton: Edward Elgar Publishing, 2001

Mannan, M.A, Ekonomi Islam: Teori dan Praktek (terj.), Jakarta: Intermasa, 1992

Miskin, Frederick, The Economics of Money, Banking and Financial Market, New York: Addison Wesley, 2003

Nasution, Anwar, Kumpulan Esay tentang Inflasi, 1997

Nasution, Chairuddin Syah, "Manajemen Kredit Syariah Bank Muamalat", http://www.fiskal.depkeu.go.id

Nugroho, Ugie, "Mekanisme PUAB bagi Ekses Dana Pihak Ketiga Perbankan", Kompas, Sabtu 3 April 2004.

Rosly, Saiful Azhar, "Mudharabah Interbank Investment", The Sun (Malaysia), Friday, Februari 16, 1996

----- "Can Islamic Banks Really Practise Musyarakah", The Sun (Malaysia), Friday. November 25,1994

, "Mudharabah and the Role of Shariah Court", The Sun (Malaysia), Friday, December 2,1994

, Islamic Banking and Economic Development", The Sun (Malaysia), Friday, August 26,1994.

March 17,1995

"Banking on Leverage", The Sun (Malaysia), Friday, "Lending is Indeed Charity", The Sun (Malaysia), Friday, November 4, 1994 
"Impact of Inflation on Deferred Sale Instruments", The Sun (Malaysia), Friday, April 28,1995

----------------, "Islamic Banking and Economic Stability", The Sun (Malaysia), Friday, May 5, 1995

March 31, 1995.

, "Banking on Productivity", The Sun (Malaysia), Friday, February 9, 1996

Saeed III, Allan H, The Impact of Inflation on Internal Planning and Control, New York: National Association of Accountants,1981

TIM BEI, “Apa Itu Bank Syariah”, BEI NEWS, Edisi 18 Tahun V, JanuariFebruari 2004 
Pengarub Inflasi Terhadap Kinerja Pembiayaan Bank Syariah 